\title{
THE EFFECT OF TURMERIC AND GARLIC PHYTOBIOTIC ADDITION WITH DIFFERENT DURATION STORAGE ON THE FUNGAL COLONY IN FEED
}

\author{
S. PURWANTI ${ }^{*}$, G. ALAM ${ }^{2}$, J.A. SYAMSU1, \\ L. AGUSTINA ${ }^{1}$, Y. SAPSUHA ${ }^{3}$, AND LISNAWATY ${ }^{4}$ \\ ${ }^{1}$ Departement of Animal Nutrition, Faculty of Animal Science \\ Hasanuddin University, Makassar 90245 South Sulawesi Indonesian \\ ${ }^{2}$ Faculty of Pharmacy Hasanuddin University, Makassar 90245 South Sulawesi Indonesia \\ ${ }^{3}$ Departement of Animal Science, AgricutureFaculltyKhaerun University, Ternate Indonesia \\ ${ }^{14}$ Alumnus Departement of Animal Nutrition, Faculty of Animal Science \\ Hasanuddin University, Makassar 90245 South Sulawesi Indonesian
}

\begin{abstract}
Turmeric and garlic phytobiotic contain bioactive substances, each of which has a function as an antifungal. The study aims to determined to test the ability turmeric and garlic phytobiotic pressed fungal colonies in the feed with different storage time. The data were analyzed by a factorial experimental design with 5 treatments 4 replications and 2 repetitions. The first factor types phytobiotic and the second factor was storage duration. R0 = basal ration (without phytobiotic), R1 = basal ration $+0.3 \%$ synthetic antifungal, $R 2=$ basal ration $+2.5 \%$ turmeric, $R 3=$ basal ration $+5 \%$ garlic, $R 4=($ basal ration + $2.5 \%$ turmeric $+5 \%$ garlic. W0,W1,W2 and W3 respectively with storage time 0, 2, 4 and 6 weeks. Samples were taken from each experimental unit homogeneously. The results showed the average fungal colonies of garlic phytobiotic treatment (26.06 $\left.\pm 44.76 \mathrm{CFU} \times 10^{3} / \mathrm{g}\right)$ in 2-week storage time $\left(25.20 \pm 22.52 \mathrm{CFU} \times 10^{3} / \mathrm{g}\right)$ lower than the provision of synthetic preservatives $\left(57.75 \pm 52.03 \mathrm{CFU} \times 10^{3} / \mathrm{g}\right)$ and the control treatment $\left(74.87 \pm 70.69 \mathrm{CFU} \times 10^{3} / \mathrm{g}\right)$. Fungal colonies increases rapidly with increasing length of time of storage. The conclusion of this study was that the additon of turmeric and garlic phytobiotic capable as an antifungal in feed.
\end{abstract}

Keywords : fungal colony, garlic, phytobiotic, storage, turmeric

\section{INTRODUCTION}

Mycotoxins produced by fungi during storage aerobic and anaerobic often not detected in the ration. This has an impact on the decline in the nutritional quality of their diets. the mechanism of action of preservatives is to decrease the $\mathrm{pH}$ of the feed so that the fungus can not grow. Alternative materials are safe and do not leave residue was phytobiotic use that has a function as an antifungal.

Utilization phytobiotic as natural growth promoters (NGPs) has been identified as an effective alternative to antibiotics. Phytobiotic as NGPs develop as a feed additive, which increases immunity, production performance and is very effective in improving the health of the digestive tract (Panda et al., 2009), stimulates livestock nutrition, antimicrobial, coccidiostatic and antihelmintic (Panda et al., 2006).
Biological response to garlic among others, include a reduced risk of cancer and antitumor, stimulation of immune function (Balasenthil et al., 2001; Song and Milner, 2001; Galeone et al., 2006; Corzo-Martǐnez et al., 2007). The antibacterial alisin reported to be effective against a large number of Gram positive and Gram negative including Salmonella, Staphylococcus, Streptococcus, Klebsiela, Proteus, Bacillus, Clostridium, Coliform and Lactobacillus, as well as some anaerobic bacteria (Rahman, 2007; Bongiorno, 2008; Saravanan et al., 2010).

\section{MATERIAL and METHODS}

\section{Collection and making of turmeric and garlic powder}

Turmeric Turina-2 obtained from Balai Tanaman Obat Aromatik, Bogor, West Java of Indonesia, with 10-month maturity, garlic kathing of traditional markets. Making the turmeric powder and garlic are two herbs 
are washed and then thinly sliced. Turmeric and garlic slices dried at a temperature of $50^{\circ} \mathrm{C}$ for 3 days. Turmeric and garlic crushed in order to obtain turmeric and garlic powder.

Ration storage with the addition of phytobiotic

Turmeric and garlic powder mixed into the ration according to treatment. Many rations each experimental unit as much as $1 \mathrm{~kg}$. Ration is placed on the board with a height of $10 \mathrm{~cm}$ from the floor. Temperature and humidity of the room is measured at any time.

\section{Sample analysis procedure}

Preparation and homogenization. Dilution of samples, take 1 gram of sample enter into $\mathrm{NaCl}$ solution $9 \mathrm{ml}$ then pipette $1 \mathrm{ml}$ of each dilution into a petri dish in simplo and Duplo. PDA (Potato Dextrose Agar) medium was added chlorampenicol $100 \mathrm{mg} / \mathrm{ml}$ after the temperature $50^{\circ} \mathrm{C}$. Pouring PDA which has previously been melted and added chlorampenicol (temperature $45-50^{\circ} \mathrm{C}$ ) $15-20 \mathrm{ml}$ into the petri dish. Wiggle the petri dish such that the mixture evenly. Allow to freeze and then incubation for 3-5 days at a temperature $22-25^{\circ} \mathrm{C}$ or room temperature. Let stand until the colony can be calculated. Fungal colonies counted after incubation the number of colonies units/gram. Fungal colony counting with the following formula

$$
N=[(1 \times n 1)+(0,1 \times n 2)+(0,01 \times n 3)] \times 10^{-3}
$$

Description :

$\mathrm{N}=$ the number of colonies of the product, expressed in colony $/ \mathrm{ml}$ or colonies/g;

$\Sigma \mathrm{C}=$ number of colonies on all the bowls were calculated;

$\mathrm{n} 1=$ number of bowls on the first dilution is calculated;

$\mathrm{n} 2=$ number of bowls on the calculated dilution;

$\mathrm{n} 3=$ number of bowls on the third dilution is calculated;

$\mathrm{d}=$ dilution first calculated .

\section{Experimental Design and Statistical Analysis}

The data were analyzed by a factorial experimental design with 5 treatments 4 replications and 2 repetitions. The first factor types phytobiotic and the second factor was storage duration. R0 = basal ration (without phytobiotic), R1 = basal ration $+0.3 \%$ synthetic antifungal, $\mathrm{R} 2=$ basal ration $+2.5 \%$ turmeric), $\mathrm{R} 3=$ basal ration $+5 \%$ garlic), $\mathrm{R} 4=$ (basal ration $+2.5 \%$ turmeric $+5 \%$ garlic). W0, W1, W2 and W3 respectively with storage time $0,2,4$ and 6 weeks.The treatments means with significant differences at $\mathrm{P}<0.05$ were compared using Least Significant Deference (LSD) (Gomez and Gomez, 1984).

\section{RESULTS and DISCUSSION}

The average number of fungal colonies in feed for different storage with the addition of turmeric and garlic phytobiotic can be seen in Table 1.

Table 1.Average number of fungal colonies in feedduringstorage contrast (CFUx103/g)

\begin{tabular}{|c|c|c|c|c|c|}
\hline \multirow[t]{2}{*}{ Treatments } & \multicolumn{4}{|c|}{ Time (weeks) } & \multirow[t]{2}{*}{ Average } \\
\hline & W0 & W2 & W4 & W6 & \\
\hline R0 & $18.00 \pm 12.73$ & $38.00 \pm 16.97$ & $62.50 \pm 40.31$ & $181.00 \pm 29.70$ & $74.87 \pm 70.69^{c}$ \\
\hline R1 & $10.50 \pm 2.12$ & $40.50 \pm 36.06$ & $54.50 \pm 20.51$ & $125.50 \pm 54.45$ & $57.75 \pm 52.03^{\mathrm{bc}}$ \\
\hline R2 & $5.50 \pm 2.12$ & $31.00 \pm 29.70$ & $41.50 \pm 17.68$ & $88.00 \pm 1.41$ & $41.50 \pm 34.51^{\mathrm{ab}}$ \\
\hline R3 & $0.25 \pm 0.21$ & $5.00 \pm \quad 0.10$ & $5.50 \pm 2.12$ & $93.50 \pm 43.13$ & $26.06 \pm 44.76^{a}$ \\
\hline R4 & $0.15 \pm 0.07$ & $11.50 \pm \quad 6.36$ & $9.00 \pm 8.49$ & $112.50 \pm 43.13$ & $33.28 \pm 51.89 \mathrm{ab}$ \\
\hline average & $17,28^{a}$ & $19,67^{a}$ & $112,84^{\mathrm{b}}$ & $121,76^{\mathrm{bc}}$ & \\
\hline
\end{tabular}

abc Different superscript at the same raw and colomn indicate significantly different $(\mathrm{P}<0.05)$ according to LSD 
Table 1 shows the addition of artificial preservatives significantly affect the number of fungal colonies during storage. The addition of turmeric and garlic phytobiotic lower than the control and the addition of calcium propionate. Control treatment there is a tendency number of fungal colonies increased more rapidly with increasing storage time. Storage time significantly affect the number of fungal colonies. The addition of garlic lower $26.06 \mathrm{CFUx} 10^{3} / \mathrm{g}$ significantly different compared with the control and the addition of calcium propionate. This shows that the addition of preservatives affect the rate of mold growth during storage. Storage long relationship with the number of fungal colonies in feed is shown by the equation $Y=1.771 x^{3}-11.74 x^{2}$ $+25.56 x+6.88$ with a correlation of $\mathrm{R} 2=0.705$. During storage up to 6 weeks of the growth rate of the number of fungal colonies move slowly with the addition of turmeric and garlic phytobiotic, but should still consider the activity of the active substances contained components.

Turmeric has antifungal activity to inhibit the growth of fungi (Wasilah et al., 2007). The greater the concentration of turmeric in the medium, the amount of active substance which diffuses into fungal cells increased resulting in fungal cells become hypertonic and various mechanisms of interference occur in yeast cells, which causes disruption of mold growth and even cause death.

Fungal colony growth in line with the amount of time there was a trend for an increase in water content, temperature and humidity. the level of contamination by fungi are largely determined by the temperature of storage, water and oxygen (Suparjo, 2008).

Alisin antimicrobial activity in their pure form, among others, as an anti-bacterial, antifungal, antiparasitic and antiviral. The antibacterial alisin reported to be effective against a large number of Gram positive and Gram negative including Salmonella, Staphylococcus, Streptococcus, Klebsiela,
Proteus, Bacillus, Clostridium, Coliform and Lactobacillus, as well as some anaerobic bacteria (Ankri and Mirelman, 1999; Bongiorno, 2008; Saravanan et al., 2010).

Action antimicrobial garlic is mainly caused by a chemical reaction between sulfur components alisin with groups of sulfur (thiol) of enzymes in microbes, such as trypsin and proteases that will affect the activity of cysteine proteinase involved virulence of some microbes (Ankri and Mirelman, 1999; Davis, 2005), which in turn causes the inhibition of microbial growth (Bakri and Douglas, 2005).

\section{ACKNOWLEDGEMENTS}

The experiment project was funded by Directorate General of Higher Education, Ministry of National Education of Republic of Indonesia (Strategis Nasional Grant 2011). The authors would like to thank to the Director General of Higher Education, Ministry of National Education of Republic of Indonesia who have provided funding. The authors would also like to the Dean of the Faculty of Animal Science and the Rector of the Hasanuddin University.

\section{REFERENCES}

Ankri, S. and D. Mirelman. 1999. Antimicrobial properties of allicin from garlic. Microb. Infect. 2: 125 - 129.

Bakri, I.M. and C.W.I. Douglas. 2005. Inhibitory effect of garlic extract on oral bacteria. Arch. Oral Biol. 50 (7): 645 - 651.

Balasenthil, S., C.R. Ramachandran, and S. Naginia. 2001. Prevention of 4-nitroquinoline 1-oxide-include rat tongue carcinogenesis by garlic. Fitoterapia.72: $524-531$.

Bongiorno, P.B., P.M. Fratellone and P. LoGiudice. 2008. Potential health benefit of garlic (Allium sativum): A narrative review. J. Compl. Integr.Med. 5 (1).

Corzo-MartÍneaz, M., N. Corzo, and M. Villamiel. 2007. Biological properties of onions and garlic. Trends Food Sci. Tech. 18: 609-625. 
Davis, R.S. 2005. An overview of the antifungal properties of allicin and its breakdown product-the possibility of a safe and effective antifungal .Mycoses.48: 95-100.

Galeone, C., C. Pelucchi, F. Levi, E. Negri, S. Franceschi, R. Talamini, A. Giacosa, and La Vecchia. 2006. Onion and garlic use and human cancer. Am. J. Clin. Nutr. 84: 1027-103.

Gomez, K.A. and A.A. Gomez, 1995. Prosedur Statistik untuk Penelitian Pertanian. Universitas Indonesia Press. Jakarta.

Panda, A. S.R. Rao, and M. Raju. 2006. Natural growth promoters have potential in poultry feeding systems. Feed tech. 10 (8): $23-35$.

Panda, A. S.R. Rao, and M. Raju. 2009. Phytobiotics, a natural growth promoter. Poultry International.pp: $10-11$.
Rahman, M.S. 2007. Allicin and other functional active components in garlic: health benefits and bioavailability. Int. J. Food Prop. 10(2): 245-268.

Saravanan, P., V. Ramya, and H. Sridhar. 2010. Antibacterial activity of Allium sativum L. on pathogenic bacterial strains. Glob. Vet. 4(5): 519-522.

Song, K. and J.A. Milner. 2001. The influence of heating on the anticancer properties of garlic. J. Nutr. 131: 1054S-1057S.

Suparjo. 2008. Teknik Penyimpanan Pakan. Fakultas Peternakan Jambi.

Wasilah, F., Syulasmi, A., and Hamdiyani, Y. 2007. Pengaruh ekstrak rimpang kunyit (Curcuma domestica Val.) terhadap pertumbuhan jamur Fusarium oxysporum Schllet secara in vitro. Seminar Nasional BIOUPI. 